\title{
Editorial - the roots of global civil society and the interwar moment
}

This special issue contends that the concept of global civil society offers a powerful analytical tool for understanding the transnational associational life that flourished across the world in the interwar years. It points to the paradoxical nature of this period, which witnessed both the de-globalization of the world and a growing sense of global interconnectivity. But it also advocates an approach attentive to the circulation and translation of ideas and practices of civil society, and to the ways in which these were embodied in the public organizations and institutions - from newspapers to peace leagues and cultural clubs - that proliferated throughout the world from the late nineteenth century onward. Finally, it invites scholars to reflect upon the varied, contingent meanings of the global - and the limits to such globalist visions.

If 'globalization' was the catchword of the 1990s, the concept of 'global civil society' only gained currency among political scientists and public policy practitioners in the early twenty-first century. However, exponents of 'global civil society', such as Mary Kaldor and John Keane, have been resolutely presentist in their approach. To these scholars, the capacity for mobilization in a 'vast, interconnected and multi-layered non-governmental space' is fundamentally novel. It is for them an unprecedented phenomenon, born of the wellspring of popular sentiment that led to the collapse of the Berlin Wall, or of the increasingly integrated global system that emerged in its wake. ${ }^{1}$ As Kaldor put it: 'what is new about the concept of civil society since 1989 is globalisation'. ${ }^{2}$ This insistence upon the novelty of these phenomena is one shared by many scholars of civil society in the non-Western world. Focusing primarily on the growth and proliferation of non-governmental organizations since the 1980s, phenomena associated with the end of the Cold War, the fall of authoritarian regimes, and growing international patronage, scholars of Africa, Asia, and Latin America have made scarce reference to the historical foundations of civic culture in these societies. ${ }^{3}$

1 John Keane, Global civil society, Cambridge: Cambridge University Press, 2001, p. 8. See also Mary Kaldor, Global civil society: an answer to war, Cambridge: Polity Press, 2003; and Gordon Laxer and Sandra Halperin, eds., Global civil society and its limits, Basingstoke: Palgrave Macmillan, 2003. For a more pessimistic assessment of late twentieth-century internationalism, see Jean-François Bayart, Global subjects: a political critique of globalisation, transl. Andrew Brown, Cambridge: Polity, 2007. On civil society tout court, see John Hall and Frank Trentmann, eds., Civil society: a reader in history, theory and global politics, Basingstoke: Palgrave, 2005; Sudipta Kaviraj and Sunil Khilnani, eds., Civil society: history and possibilities, Cambridge: Cambridge University Press, 2001; and Adam Seligman, The idea of civil society, Princeton, NJ: Princeton University Press, 1992. On the competing notion of the public sphere, see Jürgen Habermas, The structural transformation of the public sphere: an inquiry into a category of bourgeois society, transl. Thomas Burger, Cambridge: Polity, 1989; Craig Calhoun, ed., Habermas and the public sphere, Cambridge, MA: MIT Press, 1992; and Geoff Eley, 'Politics, culture, and the public sphere', positions, 10, 1, 2002, pp. 219-36.

2 Kaldor, Global civil society, p. 1. See also Arjun Appadurai, 'Grassroots globalization and the research imagination’, in Arjun Appadurai, ed., Globalization, Durham, NC: Duke University Press, 2001, pp. 1-21.

3 For a review of this literature, see Claire Mercer, 'NGOs, civil society, and democratization: a critical review of the literature', Progress in Development Studies, 2, 5, 2002, pp. 5-22. 
However, the alternative - particularly salient in studies of the Middle East - is no more satisfying: to treat the past in an instrumental fashion, as a repository of apparent precursors and precedents used to demonstrate the possibility of a lively contemporary civil life. ${ }^{4}$

While remaining wary of such reification, we reach rather further back in time than scholars such as Kaldor and Keane to track the emergence of global civil society as a set of notions and processes. Throughout the long nineteenth century, surging international trade, fuelled by the rapid circulation of labour, capital, and commodities, facilitated the creation of new connections and dependences spanning the world. ${ }^{5}$ To put it succinctly: globalization made global civil society possible. The uneven transformation of the globe into a single, coalstreaked sphere of exchange was accompanied by the emergence, from Buenos Aires to Beirut, and from Paris to Penang, of civil society institutions. In all these places, cultural clubs, philosophical and learned societies, charitable organizations, and reformist leagues appeared in ever-growing numbers. Their members increasingly thought, and acted, globally. ${ }^{6}$ The spread of the telegraph and the growing ubiquity of print media, meanwhile, provided politically conscious men and women the world over with the means to exchange ideas and put their claims before the world. As Juan Cole and Mark Frost have argued, such novel technologies were far more than mere 'tools of empire' 7 On the contrary, the West's control over these instruments of globality was forever challenged by their appropriation by non-Westerners. ${ }^{8}$

The ideas of freedom, political representation and equality, reform, and moral amelioration that circulated throughout these networks were translated, debated, and discussed by figures as varied as the British theosophist and social campaigner Annie Besant, the Yoruba Anglican bishop Samuel Ajayi Crowder, and the polymaths Rammohan Roy in Calcutta and Lim Boon Keng in Singapore. ${ }^{9}$ By the turn of the century, women's rights activists and peace campaigners, anarchists and Marxists, abolitionists and religious revivalists had all created movements that ran across, and sometimes undercut, borders.

These literati, campaigners, and reformers drew upon a shared palette of ideas and practices. They established associations, committees, and leagues, and congregated at international conferences and assemblies; they founded printing presses, schools, and

4 See, for instance, Saad Eddin Ibrahim, 'Civil society and prospects for democratisation in the Arab world', in Augustus R. Norton, ed., Civil society in the Middle East, vol. 1, Leiden: Brill, 1995, pp. $27-54$.

5 For discussions of the historical reach of globalization, and the ways in which historians might use the term, see C. A. Bayly, The birth of the modern world, 1780-1914: global connections and comparisons, Oxford: Blackwell, 2004; Frederick Cooper, 'Globalization', in Colonialism in question: theory, knowledge, history, Berkeley, CA: University of California Press, 2005, pp. 91-112; and A. G. Hopkins, ed., Globalisation in history, London: Pimlico, 2002.

6 John A. Hall and Frank Trentmann, 'Contests over civil society: introductory perspectives', in Hall and Trentmann, Civil society, pp. 2, 3.

7 Daniel Headrick, The tools of empire: technology and European imperialism in the nineteenth century, Oxford: Oxford University Press, 1981.

8 Juan Cole, 'Printing and urban Islam in the Mediterranean world, 1890-1920', in Leila Tarazi Fawaz and C. A. Bayly with Robert Ilbert, eds., Modernity and culture from the Mediterranean to the Indian Ocean, New York: Columbia University Press, 2002, p. 346; Mark Frost, 'Asia's maritime networks and the colonial public sphere, 1840-1920', New Zealand Journal of Asian Studies, 6, 2, 2004, p. 67.

9 See C. A. Bayly, 'Rammohan Roy and the advent of constitutional liberalism in India, c. 1800-1830', Modern Intellectual History, 4, 1, 2007, pp. 25-41; T. N. Harper, 'Globalism and the pursuit of authenticity: the making of a diasporic public sphere in Singapore', Sojourn, 12, 2, 1997, pp. 275-7; J. D. Y. Peel, Religious encounter and the making of the Yoruba, Bloomington, IN: University of Indiana Press, 2000. 
universities, and established newspapers, magazines, and learned journals, regarding the periodical press as a vehicle of civic life. Moreover, they spoke insistently of the public, conceiving of it as an entity at once distinct from the state - and capable of holding it to account from a distance - yet bound to it by ties of mutual obligation and interchange. However, these actors did far more than adopt such concepts, more usually associated with the growth of Western liberal democracy, wholesale. Rather, they reworked and customized them, sometimes fitting them to local circumstances, at other times extending their scope and making them, in the process, truly global. ${ }^{10}$ These trends, we argue here, came to a head in the interwar years. Local, colonial, and national public spheres grew increasingly interconnected in these decades, as transnational organizations multiplied in number and expanded in scope, and as new, supranational architectures of international relations were conceived - and contested. ${ }^{11}$

The concept of global civil society therefore provides a powerful analytical framework for a new generation of historians intent upon tracking such transnational movements and associational networks. Drawing upon a disparate range of regional historiographies and thematic approaches, from the 'new international history' of institutions, organizations, and movements to a 'global intellectual history' privileging translation and convergence over mere diffusion, these scholars move beyond past attempts to trace the genealogies of civil society to the canonical texts of European political thought. ${ }^{12}$ Rather, they examine the ways in which notions of civil debate and ethical conduct were embodied, and transformed, across the world through the proliferating institutions of the public sphere. ${ }^{13}$ Furthermore, they stress the emergence in multiple centres around the world of analogous practices of association and claim-making. Finally, they examine the inception of an aspirational and imagined global community above and beyond the imperial or national state, to which activists, literati, and professionals appealed in order to challenge the state and transform local societies. The idea of a common humanity based on freedom, justice, and equality, regardless of race, class, or creed, was not simply a radical Enlightenment ideal, but was felt, lived, and employed in different, sometimes contradictory, ways by multiple actors in this period - from the embattled imperialists and anti-colonial petitioners of the 'Wilsonian moment' to Asian and African trade unionists, professionals, and literati.

10 This point owes much to the argument of Chris Bayly in C. A. Bayly et al., 'AHR conversation: on transnational history', American Historical Review, 111, 5, 2006, p. 1461.

11 See Handbook of international organisations, Geneva: League of Nations, 1929 and 1931; L. C. White, The structure of private international organizations, Philadelphia, PA: George S. Ferguson Company, 1933; and Les 1978 organisations internationales fondées depuis le Congrès de Vienne, Brussels: Union of International Associations, 1957.

12 For recent historical works that examine the development of humanitarian ideas and practices through the twentieth century, see Akira Iriye, Global community: the role of international organizations in the making of the contemporary world, Berkeley, CA: University of California Press, 2002; Mark Mazower, No enchanted palace: the end of empire and the ideological origins of the United Nations, Princeton, NJ: Princeton University Press, 2009; Samuel Moyn, The last utopia: human rights in history, Cambridge, MA: Harvard University Press, 2010; Jay Winter, Dreams of peace and freedom: utopian moments in the twentieth century, New Haven, CT: Yale University Press, 2006.

13 For examples of such an approach, which explicitly make use of the notion of civil society, see Philip Nord, The republican moment: struggles for democracy in nineteenth-century France, Cambridge, MA: Harvard University Press, 1995; and Frank Trentmann, Free trade nation: commerce, consumption, and civil society in modern Britain, Oxford: Oxford University Press, 2008. 
By bracketing together contributions on locales as varied as Dar es Salaam, Bangkok, and Geneva, and highlighting the connections that ran between them, we seek both to transcend the Atlantic focus of much work on civil society and to break down resilient boundaries between - in that pat phrase - 'the West and the rest' ${ }^{14}$ For instance, the circulation of seemingly 'Western' ideas and practices often flowed into and converged with long-standing vernacular traditions in Asia and Africa - as Lewis shows in her examination of the ways in which Southeast Asian cosmopolitans reconciled the Rotary rhetoric of 'service above self' with Asian notions of community and philanthropy. The near-simultaneous engagement of actors across the world with the norms and forms of public life gives pause to those who might still insist upon the exceptional nature of Euro-American civil society, and the tardy, incomplete take-up of its ideas in the world beyond. However, these linkages should not obscure the enduring sense among Europeans of their own continent's centrality to the world and its affairs, apparent in Richard's discussion of the interaction between advocates of the League of Nations and of European cooperation. Nor should it blind us to the ways in which the practices of transnational associational life, far from serving only emancipatory ends, were frequently harnessed - as Marilyn Lake and Henry Reynolds have reminded us - to exclusionary projects. ${ }^{15}$

The notion of global civil society also provides us with a conceptual lens through which to view the interplay between different scales of mobilization, from agitation for a worldwide 'parliament of man' to new regional alignments, such as pan-Africanism, pan-Asianism, panAmericanism, or, indeed, pan-Europeanism - themes that feature in the articles of Hunter, Stolte, and Richard - and local appropriations of the lexicons of cosmopolitanism and globalism. Such discourses, despite their potential to traverse and transgress borders, did not always corrode more parochial attachments and frames of reference. Hunter, for instance, shows how Mambo Leo, a Swahili-language newspaper established and funded by the administration of British-ruled Tanganyika, served to buttress both the local state and the international institutions that had imbued it with legitimacy, while nevertheless creating a forum through which the territory's inhabitants could imagine new alignments - from imperial cosmopolitanism and pan-Africanism to local-level unity. Stolte, meanwhile, shows how Indian trade unionists used the language of pan-Asianism to campaign for broader representation on the global stage of the International Labour Organization.

Indeed, it should not be forgotten that actors in these years rarely made hard-and-fast choices between different levels of belonging and activism. Rather, they moved up and down the scales of mobilization, sometimes engaging intensely with their immediate surrounds, at other times seeking to broker broader, cross-border understandings and alliances, integrating various levels of engagement. Furthermore, many jumped easily from one role to another, taking on different, and sometimes conflicting, positions. As Richard and Wertheim both show, the lines between official function and civil advocacy were often blurred by the activities of men such as Léon Bourgeois, who juggled his position as one of France's envoys to the Peace Conference of 1919 with his presidency of the Association Française de la

14 For a similar argument about cosmopolitanism, see Glenda Sluga and Julia Horne, 'Cosmopolitanism: its pasts and practices', Journal of World History, 21, 3, 2010, pp. 369-74.

15 Marilyn Lake and Henry Reynolds, Drawing the global colour line: white men's countries and the international challenge of racial equality, Cambridge: Cambridge University Press, 2008. 
Sociéte des Nations. ${ }^{16}$ In similar fashion, some of the Asian Rotarians whom Lewis examines combined state employment with a thorough engagement in associational life. Such fluidity reminds us that the boundaries between the state and civil society were never watertight. Instead, they remained forever porous, as personnel moved freely back and forth between one and the other. Far from monolithic constructs standing at a distance from each other, they were both loose congeries of institutions and personnel, which often bled into one another.

Moreover, examining the workings of the global civil society of the early twentieth century renders us more attentive to the shifting, multiple meanings that the 'global' took on for historical actors. For some, like the Rotary members whose activities and pronouncements Lewis examines, to be global was to belong to a larger, transnational movement that stressed internationalism and cross-cultural cooperation - but also to use such ideals to break down the racial hierarchies of colonial society in Southeast Asia. These campaigners did not seek to work at the level of the world, but to bring the local and the global into conversation. They - and others, such as Boy Scouts and Young Women's Christian Association (YWCA) members from Aleppo and Nairobi to Kuala Lumpur and Shanghai drew strength from the mere knowledge of belonging to broader, global, networks of association, even as they refused to renege upon the local life in which they remained entangled. ${ }^{17}$ As John Keane has pointed out, 'the liveliest local civil societies are those enjoying the strongest links with global civil society'. ${ }^{18}$ By the same token, however, others such as the Eastern Mediterranean literati and publicists of New York, Paris, and Cairo, whose writings Arsan examines - firmly conceived of their actions as global in scope, but local in outcome, attempting to secure reforms for their homelands, first from the Ottoman state, then from the Mandatory rulers of the new states of Lebanon and Syria, largely through transnational campaigns and conferences. These were, then, but two dimensions or permutations of the global that historical actors conceived of: on the one hand, engaging locally with global networks and causes; on the other, mobilizing globally for localized aims. More generally, organizations such as the Inter-Parliamentary Union or the International Federation of League of Nations Unions (which feature in the contributions of Albers and Richard, respectively) repeatedly emphasized that a firm grounding in local circumstances would facilitate global understanding. Attending to these different understandings of the global and its relation to more circumscribed spheres of political activity may enrich our understanding of what Emma Rothschild has termed the 'idea of globalisation'. ${ }^{19}$

16 Patricia Clavin, 'Defining transnationalism', Contemporary European History, 14, 4, 2005, p. 425. See also M. Herren, 'Modernisierung, Aussenpolitik und Integration im Jahrhundert des Internationalismus', Historische Mitteilungen, 7, 1, 1994, p. 6.

17 See Keith Watenpaugh, Being modern in the Middle East: revolution, nationalism, colonialism, and the Arab middle class, Princeton, NJ: Princeton University Press, 2006; Timothy H. Parsons, Race, resistance, and the Boy Scout movement in British colonial Africa, Athens, OH: Ohio University Press, 2004; Janice Brownfoot, 'Sisters under the skin: imperialism and the emancipation of women in Malaya, c.1891-1941', in J. A. Mangan, ed., Making imperial mentalities: socialisation and British imperialism, Manchester: Manchester University Press, 1990; Emily Honig, Sisters and strangers: women in the Shanghai cotton mills, 1919-1949, Stanford, CA: Stanford University Press, 1986.

18 Keane, Global civil society, p. 25.

19 Emma Rothschild, 'Arcs of ideas: international history and intellectual history', in Gunilla-Friederike Budde, et al., eds., Transnationale Geschichte: Themen, Tendenzen, Theorien, Göttingen: Vandenhoek and Ruprecht, 2006, p. 218. 
Nevertheless, our use of the term should not blind us to the limits of global civil society. The claims to civility and reciprocity of some - such as, for instance, the pan-Africanist writer W. E. B. Dubois - could be rejected by others, who regarded them as lying beyond the pale of a community of civilized states whose boundaries neatly corresponded with the fringes of whiteness. ${ }^{20}$ After all, the emphatic insistence of the Middle Eastern propagandists and literati whom Arsan examines on the global reach of the principle of self-determination ultimately fell on deaf ears. More than this, partaking in the institutions of civil society was often, in itself, an exclusionary act. Thus, as Hunter argues, the civic space created by the Tanganyikan and Cameroonian press was one that not only promoted imperial citizenship but also found no room for those who did not share such ideals. At a more general level, associational life was often a way for individuals to mark themselves off from others who remained outside its select circles. Joining a temperance society or diligently attending the proceedings of a cultural club, making charitable contributions or signing petitions were all means for men and women, in Calcutta and Cape Town as much as in New York or Hamburg, to constitute themselves as middle-class subjects, respectable figures worthy of assuming the mantle of civility.

By the 1920s and 1930s, however, such institutions were no longer entirely the purview of a small, highly educated, and often privileged elite that felt vested with the authority to 'speak for the world'. Rising educational levels, increased access to information, and new opportunities for social mobility drove more men and women to immerse themselves in associational life. The emergence of global civil society was facilitated by the ability of nonWestern intellectuals to forge trans-local connections thanks to a common education in imperial and regional lingua franca such as French, English, standardized Arabic, Chinese, Swahili, or Malay. Such experiences helped them imagine communities not just at the level of the nation, as Benedict Anderson famously argued, but also at the level of the region and the world. ${ }^{21}$ To an emerging professional class of doctors and lawyers, teachers and journalists, such public undertakings were not simply local matters, or strategies by which they could distinguish themselves from those below them in the social order and challenge the claims to representativeness of those above, as Charles Maier argued a generation ago. ${ }^{22}$ On the contrary, the making of middle-class selves was an inherently transnational process: those caught up in it did not just define themselves in local terms; they also drew comparisons with others elsewhere, and seized upon circulating repertoires of practices - from consumption and philanthropy to thrift and political participation. ${ }^{23}$

The interwar years, we argue, provide a privileged vantage point from which to examine the meanings, extent, and limits of transnational associational life. This was, of course,

20 Gerritt W. Gong, The standard of 'civilization' in international society, Oxford: Clarendon, 1984.

21 Benedict Anderson, Imagined communities: reflections on the origin and spread of nationalism, London: Verso, 1991.

22 Charles Maier, Recasting bourgeois Europe: stabilization in France, Germany, and Italy after World War One, Princeton, NJ: Princeton University Press, 1975. For an account of a non-European middle class attentive to its participation in the public sphere, and to strategies of differentiation, see Sanjay Joshi, Fractured modernity: making of a middle class in colonial north India, New Delhi: Oxford University Press, 2001.

23 On this, see Cyrus Schayegh, Who is knowledgeable is strong: science, class, and the formation of modern Iranian society, 1900-1950, Berkeley, CA: University of California Press, 2009; and Watenpaugh, Being modern. 
a time of growing introspection and rising ethnic nationalism, of closing borders and anxious protectionist sentiment. However, it was also, paradoxically, the heyday of a vigorous internationalism, and one that reached further than ever before, across the world. ${ }^{24}$ The First World War was in many ways a truly global conflagration. The conflict did not simply pit peoples against each other, leading to a resurgence of nationalism and irredentism. It also bred a growing sense of interconnectedness, as people from the world over were drawn into the conflict both directly through service on the battle-lines, the home front, and in peace leagues and vicariously through the news agency wires, whose constant reporting of developments fostered a striking sense of simultaneity.

The carnage of the battlefields also chipped away at the worn veneer of European civilization, sowing existential doubt among Europeans, and conjuring up for colonized peoples the tantalizing possibility of concessions from the imperial behemoths. ${ }^{25}$ As Erez Manela has reminded us, while the proceedings of the Paris Peace Conference of 1919 remained a firmly Western affair, vain hopes of reform and self-determination brought a motley crowd of panAfricanists, Asian literati, and political leaders and emissaries to the City of Light. ${ }^{26}$ Others, however, were already seeking alternative avenues of mobilization, turning for inspiration to the radical discourses suddenly brought to the fore of global consciousness by the October Revolution of 1917.

Indeed, this was not an age entirely dominated by the Western institutions upon which some international historians have tended to focus. While the League of Nations itself in many ways buttressed European imperialism, the new institutions of international civil society also provided some Asians and Africans with a tribune upon which to stake their claims, and a novel language in which to make them, from demands for self-determination and international recognition to calls for the protection of minority rights. ${ }^{27}$ As Manela and Toby Dodge have argued, the decision to allow India to enter the League, and the establishment of the Mandate systems, did not just create in Egyptians or Iraqis a sense of expectation; it also gave them the conviction that their desires were entirely legitimate in the eyes of the international community - and could, indeed, be achieved only with its assent. ${ }^{28}$ For, as David Armitage has reminded us, any declaration of independence must be a 'global event', made before the gaze of the world. ${ }^{29}$

24 On the paradoxical nature of the interwar period, see Zara Steiner, The lights that failed: European international history, 1919-1933, Oxford: Oxford University Press, 2005.

25 For European decline, see Oswald Spengler, Der Untergang des Abendlandes: Umrisse einer Morphologie der Weltgeschichte, München: O. Beck, 1918-22; Paul Valéry, 'La crise de l'esprit', in Variété, vol. 1, Paris: Nouvelle Revue Française, 1924. For reactions in Asia and Africa, see Prasenjit Duara, 'The discourse of civilization and Pan-Asianism', Journal of World History, 12, 1, 2001, pp. 99-130; and Michael Adas, 'Contested hegemony: the Great War and the Afro-Asian assault on the civilizing mission ideology', Journal of World History, 15, 1, 2004, pp. 31-63.

26 Erez Manela, The Wilsonian moment: self-determination and the international origins of anticolonial nationalism, New York: Oxford University Press, 2009.

27 Susan Pedersen, 'Back to the League of Nations', American Historical Review, 112, 4, 2007, pp. 1091-1117.

28 Toby Dodge, Inventing Iraq: the failure of nation building and a nation denied, London: Christopher Hurst, 2003.

29 David Armitage, The declaration of independence: a global history, Cambridge, MA: Harvard University Press, 2007, p. 12. 
The appearance of powerful novel transnational institutional models such as the Young Men's Christian Association, meanwhile, inspired Asians to form their own associations. Bodies such as the Young Men's Buddhist Associations in Colombo and Rangoon, or the Young Men's Muslim Association in Cairo, fostered a pride in cultural specificity even as they appealed to the ecumenical linkages of world religion. The spread of seemingly 'Western' ideals of internationalism therefore resonated with existing notions of community and cosmopolitanism in different locales across the world, fostering unintended consequences and producing new languages and practices of participation in global civil society.

Furthermore, it would be wrong to see the interwar years as marking the emergence of an entirely new world order. These were decades in which formal edifices of international life such as the League of Nations and the International Labour Organization were constructed. And they were also a period of unprecedented popular enthusiasm for transnational associational life, in which various competing calls to global affinity - from the older forms of imperial community that underlay the Scout movement to the internationalism of the YWCA and the Rotary, to the cross-cutting networks of anti-colonial mobilization and the Communist International - jostled and clamoured for the attention of men and women from North America and western Europe to India and Southeast Asia. ${ }^{30}$ However, the seemingly novel constructs of the entre-deux-guerres built upon, but also breathed fresh life into, older forms of transnational mobilization and associational life. The Inter-Parliamentary Union and, indeed, the League of Nations - had their origins (as Albers and Wertheim remind us) in the associational ferment of the late nineteenth and early twentieth centuries.

Yet the fraught decades of the 1920s and 1930s also witnessed the growing prominence, and cohesiveness, of 'old networks forged across the Afro-Asian world'. ${ }^{31}$ As Arsan argues, Eastern Mediterranean engagement with the League of Nations drew upon diasporic connections and modes of interaction with the international community that had been established in the years before 1914. Similarly, Lewis points to the ways in which Rotary's cross-cultural appeal accorded well with the multi-ethnic associational life of Asia's port cities, born of the high degrees of migration within this commercial maritime arena. Thus, while we seek to examine the specific dynamics of global civil society in the interwar years, that heyday of internationalism, we also wish to frame the period in a longer historical context, casting light on the prehistory of phenomena whose origins scholars have all too often traced to the welter of destruction that was the Great War. In doing so, we hope to open up new vistas on the history both of the interwar years and of global civil society itself.

The concept of global civil society, we have argued here, is a powerful lens through which historians may scrutinize a variety of ecumenical ideals and globalist movements. The contributions collected in this special issue reflect a range of ways in which ideas of global civil society were experienced and embodied. Arsan traces the diasporic public sphere through which Eastern Mediterranean reformist thinkers sought to influence the policies of

30 On the linkages and exchanges between various groups of anti-colonial nationalists, see Elleke Boehmer, Empire, the national, and the postcolonial, 1890-1920, Oxford: Oxford University Press, 2002; and Harald Fischer-Tiné, 'Indian nationalism and the "world forces": transnational and diasporic dimensions of the Indian freedom movement on the eve of the First World War', Journal of Global History, 2, 3, 2007 , pp. 325-44.

31 T. N. Harper, 'Empire, diaspora, and the languages of globalism', in Hopkins, Globalization in history, p. 158. 
the Ottoman empire and its European partners. Albers documents the hopes and disappointments of participants in the Inter-Parliamentary Union. Wertheim exhumes the fraught process by which transatlantic campaigns for a strong, 'legalist-sanctionist' international organization gave way to the creation of the 'softer', more political than legal, institution of the League of Nations. Richard investigates the complementary visions for global and regional cooperation in the networks surrounding the League of Nations. Stolte explores the international platforms that Indian trade unionists used to express Asian solidarity. Hunter examines the discourses of belonging that circulated through the print worlds of interwar Tanganyika and Cameroon. Finally, Lewis studies the role of international organizations such as Rotary in creating a multi-ethnic associational space in Southeast Asia.

In different ways, all these contributions underline the particular, paradoxical quality of the 1920s and 1930s - decades that witnessed at once a de-globalization of the world and an unprecedented vigour for transnational associational life. While many states battened down the hatches in the 1930s, disavowing free trade and increasingly erecting barriers to human movement, some of their citizens attempted to keep the windows open, building on older networks and mechanisms of international cooperation and global civility. More broadly, these articles invite us to reflect upon the variegated and contingent meanings of the global, and the diverse ways in which historical actors envisioned their participation in a terrestrial community of states and citizens - a participation often underwritten by ideals of freedom, representation, equality, and brotherhood, as well as by shared associational practices. But they also alert us to the limits to such ecumenical visions. For transnational mobilization, lest we forget, could all too easily serve exclusionary ends. The contributions to this volume move beyond resilient regional divisions and rigid disciplinary boundaries to stress the multidirectional and multi-centred terrain of global civil society across the world, and the networks and connections that ran through it. However, they do not seek to provide the last word on the shifting contours of global civil society, but merely to invite others to embark upon paths not taken. 